\title{
Clinical Study Follow-up
}

National Cancer Institute

\section{Source}

National Cancer Institute. Clinical Study Follow-up. NCI Thesaurus. Code C99158.

A period in a clinical study during which information about the health status of an individual is obtained after study procedures and treatments have concluded. 